\title{
Abstract
}

\section{First evidence of marine influence in the Cretaceous of the Amazonas Basin, Brazil}

\author{
D.F. Rossetti ${ }^{a} *$, R.G. Netto ${ }^{b}$ \\ ${ }^{a}$ INPE, Rua dos Astronautas 1758, Jardim da Granja-CP 515, 12245-970 São José dos Campos-SP, Brazil \\ ${ }^{\mathrm{b}}$ PPGeo UNISINOS, Av. Unisinos, 950, 93022-000 São Leopoldo, RS, Brazil \\ Received 27 April 2005; accepted in revised form 6 October 2005
}

An integrated investigation emphasizing sedimentological and ichnological studies of Cretaceous deposits of the Alter do Chão Formation, exposed in the western Amazonas Basin, was undertaken with the aim of determining depositional environments. Four facies associations attributed to upper shoreface, foreshore, delta mouth bar, and lower/middle shoreface-prodelta depositional environments are recognized. The upper shoreface deposits were deposited by storm flows. They are interbedded with highly bioturbated sandstones displaying Thalassinoides, Planolites and Diplocraterion traces. The foreshore deposits, which are coarser-grained than the shoreface strata, are characterized by tabular sandstones displaying planar or trough cross-lamination/stratification, wavy/flaser lamination, and parallel lamination. These strata also contain an abundance of trace fossils. The delta mouth bar deposits comprise upward-coarsening beds displaying a lobed geometry. The lower/middle shoreface-prodelta settings consist of well-stratified, very fine-grained sandstones and mudstones deposited mostly by storm action. A wavedominated delta system that prograded into a marine-influenced basin is supported for the study area. Therefore, in contrast to previous interpretations, it seems that a widespread Cretaceous transgression resulted in the submergence of large continental areas in the north of Brazil, affecting sediment deposition even in the innermost portions of the intracratonic Amazonas Basin.

(C) 2006 Elsevier Ltd. All rights reserved.

Keywords: Cretaceous; Amazonas Basin; Marine influence; Sedimentary facies; Ichnology

\section{Introduction}

The distinction between open marine and continental strata in the geological record is, in general, straightforward, but the recognition of transitional depositional settings can be problematic because they produce sediments formed by a mixture of marine and non-marine processes. Interpretations are particularly problematic in successions that lack fossils, analysis of the depositional setting having to rely solely on an understanding of the physical sedimentary structures. Many papers published in recent years have contributed to our knowledge of the sedimentary imprint of marine processes, particularly involving tidal

\footnotetext{
* Corresponding author.

E-mail addresses: rossetti@dsr.inpe.br (D.F. Rossetti), nettorg@euler. unisinos.br (R.G. Netto).
}

currents and storm waves (e.g., Boersma and Terwindt, 1981; Dott and Bourgeois, 1982; Walker, 1984; Yang and Nio, 1985; McCrory and Walker, 1986; Arnott and Southard, 1990; Leckie and Singh, 1991; Nio and Yang, 1991; Shanley et al., 1992; Arnott, 1992, 1993; Cheel and Middleton, 1993; Hadley and Elliot, 1993; Amos et al., 1996). As a result, many deposits recorded in the literature previously as continental may be partly of marine origin.

The sedimentological criteria that aid recognition of tidal and storm deposits have helped to provide new interpretations of many Cretaceous deposits exposed in the north Brazilian marginal basins, which are dominated by transitional marine deposits. Hence, a number of studies undertaken during the past ten years on exposures of Albian-Cenomanian rocks of the São Luís-Grajaú and Cametá (Marajó Graben System) basins, have demonstrated the significance of tidal currents and storm waves as dominant depositional agents, even in southernmost

0195-6671/\$ - see front matter (C) 2006 Elsevier Ltd. All rights reserved. doi:10.1016/j.cretres.2005.10.014 
115 areas at the basin margins, located several hundreds of kilo116 metres from the modern coastline (e.g., Rossetti, 1998; Rossetti 117 et al., 2000; Rossetti and Santos Jr., 2003; Rossetti and Góes, 118 2004). They have shown that shallow-marine to transitional en119 vironments were extensive as a result of widespread marine in120 cursions throughout these basins, in contrast to previous 121 suggestions of an entirely continental origin (e.g., Petri and Fúl122 faro, 1983). Transgressions of such magnitude should have had 123 an influence on adjacent regions to the west in the intracratonic 124 Amazonas Basin, which has been of low overall relief since at 125 least the Cretaceous Period. However, no marine or marginal 126 marine sediments have been recorded previously from the Cre127 taceous of this basin. The 500-m-thick Alter do Chão Formation 128 is composed of siliciclastic red beds (sandstones and mud129 stones) that have been interpreted as continental in origin 130 (e.g., Daemon, 1975; Dino et al., 1999), but a lack of widespread 131 fossil collecting and sedimentological studies has precluded full 132 recognition of the sedimentary processes that led to its 133 development.

134 This paper provides a detailed description of the sedimen135 tary features preserved in the Alter do Chão Formation where 136 it crops out along the left side of the Amazonas River near 137 Careiro Island, about $50 \mathrm{~km}$ to the east of Manaus, in the mid138 dle of the Amazonas Basin (Fig. 1). Our investigation has 139
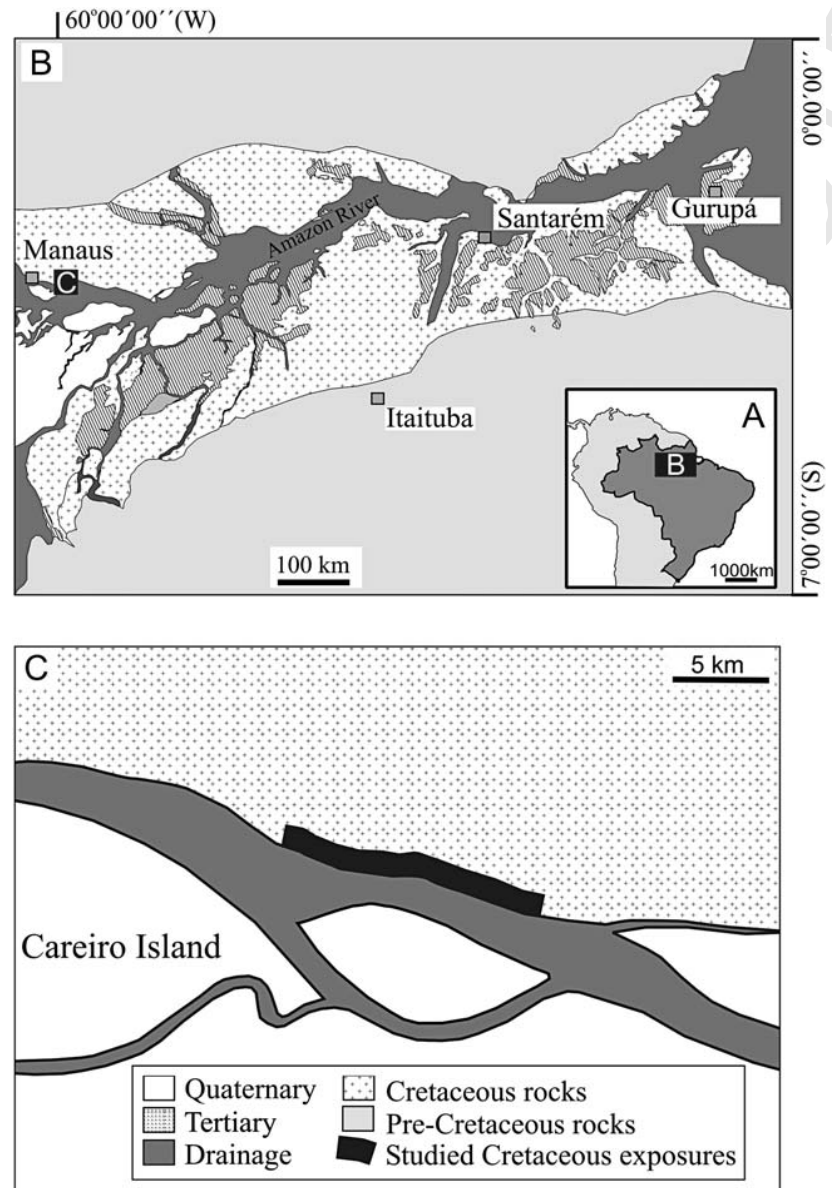

Fig. 1. A-C, location maps of the study area in Amazonas State, northern Brazil; the band of exposures of Cretaceous rocks along the riverbank to the north of the Careiro Island is shown in $\mathrm{C}$. revealed a set of exposures with well-preserved physical and biogenic structures, allowing detailed interpretations of their mode of origin. Hitherto, studies of this nature had not been carried out on the formation, our knowledge of it having had to rely mostly on regional geological studies. In this paper, we integrate sedimentological and ichnological interpretations and conclude from these that the formation is not entirely continental in origin, features suggesting marine influence being abundant throughout the exposures. Our data lead us to suggest that Cretaceous transgressions might have been much more widespread in Brazilian territory than previously thought, resulting in the submergence of large continental areas, even within intracratonic basins.

\section{Geological framework}

The Amazonas Basin covers an area of up to $500,000 \mathrm{~km}^{2}$, and is bounded by the Purus and Gurupá arcs to the west and east, which separate this basin from the Solimões and Marajó basins, respectively. It is limited to the north by the Guiana Shield and to the south by the Brazilian Shield. The basement comprises igneous, metamorphic and volcano-sedimentary rocks of the Maroni-Itacaiunas and Amazônia Central provinces, which correspond to the oldest rocks of the Amazon Craton (Teixeira et al., 1989; Tassinari and Macambira, 1999; Tassinari et al., 2000). Near the Purus Arch, this basin is underlain by Proterozoic sedimentary rocks belonging to the Purus Group (Eiras et al., 1993).

The structure of the Amazonas Basin is defined by an eastwest and a southwest-northeast orientated central trough, bounded by two platforms located to the north and south. Its origin is related to a rifting event controlled by Early Paleozoic intraplate extension. As the rift evolved, four main phases of deposition took place, which alternated with periods of thermal subsidence. The main trough, where the depocenter is located, contains four sedimentary successions, collectively up to $6500 \mathrm{~m}$ thick, which developed during the OrdovicianEarly Devonian, Devonian-Early Carboniferous, Middle Carboniferous-Permian and Mesozoic-Cenozoic. The last succession is up to $500 \mathrm{~m}$ thick, and consists of the Javari Group (Cunha et al., 1994; Eiras et al., 1994), formed due to east-west extension associated with both the evolution of the South Atlantic Ocean and the Andean Cordillera. The Alter do Chão Formation, the subject of this paper, records the Cretaceous sedimentation of this group. Defined for the first time by Kistler (1954), it comprises red-coloured sandstones, mudstones, conglomerates and intraformational breccias, traditionally attributed to high-energy, westward-flowing fluvial and lacustrine/deltaic systems (Daemon, 1975). Its Cretaceous age was first suggested on the basis of therapod teeth (Price, 1960), with later papers considering it as Cenomanian-Maastrichtian (Daemon and Contreras, 1971), and middle AlbianTuronian (Daemon, 1975). Subsurface information (e-logs and a few cores) from areas located a few kilometres from the localities reported here led to the recognition of two sedimentary successions within the formation: an upper Aptian/lower Albian meandering to anastomosed fluvial and eolian unit; and 
an upper Cenomanian fluvio-deltaic unit (Dino et al., 1999), the latter including the deposits described here.

\section{Sedimentological and ichnological descriptions}

The Alter do Chão Formation is exposed in the study area along a series of riverbanks that are up to $20 \mathrm{~m}$ high and, in general, several tens of metres long. Despite their discontinuous nature, which makes stratigraphic correlation difficult, these deposits display several internal features that provide good insights into the depositional processes. Furthermore, the strata are sufficiently well exposed and well preserved in the lower and middle reaches of the sections to provide information on facies relationships and, in some cases, geometry, thus allowing discussions of the depositional environment. Unfortunately, micropaleontological and palynological data that could help with the interpretation of the depositional setting are unavailable, but an abundance of ichnofauna aids discussion of the depositional processes and environments.

The deposits studied are typically red beds that are bounded at the top by a discontinuity surface with a mottled soil horizon that locally displays lateritic concretions. This surface is overlain by yellowish, fine- to coarse-grained friable sands, tentatively attributed to the Plio-Pleistocene Post-Barreiras sediments by comparison with similar deposits exposed in northeastern Amazonia (e.g., Rossetti et al., 1989; Rossetti and Góes, 2001). The exposures of the Alter do Chão Formation consist of moderately to well-sorted, fine- to coarsegrained, and locally conglomeratic, sandstones that are interbedded with thin layers of mudstones. A variety of sedimentary structures characterize the sandstones that, for descriptive purposes, can be regarded as 12 facies (Table 1). The mudstones are less variable, consisting of two sedimentary facies. The sandstones and mudstones can be organized into four facies associations, described below and summarized in Table 2. Facies associations A, B and D are widespread throughout the study area, while facies association $\mathrm{C}$ occurs only in the northwestern part, conformably overlying the other deposits.

\subsection{Facies association A}

These deposits (Fig. 2A-H) consist entirely of white to yellowish and light purple/red, very fine- to fine-grained sandstones that occur as a series of laterally continuous, tabular beds up to $3 \mathrm{~m}$ thick, with the whole association reaching up to $9 \mathrm{~m}$ thick. A variety of either well-stratified or massive sandy facies is present. Well-stratified sandstones form strata with lower boundaries that are typically undulating and erosional, and locally separated by thin mudstones or lags of mud chips and pebbles. Internally, these beds display largescale, low-angle dipping strata (facies $\mathrm{Su}$, see no. 1 in

Table 1

Summary of the sedimentary facies recognized in the study area, with the interpreted depositional processes

\begin{tabular}{lll}
\hline Sedimentary facies & Description & Depositional processes \\
\hline Sqp & $\begin{array}{l}\text { Well-sorted, fine-grained sandstone with quasi-planar } \\
\text { lamination with frequent reactivation surfaces }\end{array}$ & $\begin{array}{l}\text { Deposition of flat beds under variable upper flow regime with unidirectional } \\
\text { and oscillatory motion }\end{array}$ \\
& $\begin{array}{l}\text { Well-sorted, fine- to medium-grained sandstone with } \\
\text { large scale, low-angle dipping stratification with }\end{array}$ & $\begin{array}{l}\text { Migration of large scale, but low amplitude bedforms under variable lower } \\
\text { flow regime with unidirectional and oscillatory motion (the latter being } \\
\text { frequent reactivation surfaces and/or mud drapes }\end{array}$ \\
Moderate to well-sorted, fine- to medium-grained & subordinate) \\
Sw & Migration of sinuous-crested bedforms under variable, lower flow regime \\
& hummocky cross-stratification with frequent reactivation & with unidirectional and oscillatory motion (with a greater contribution of the
\end{tabular}

Sx Poorly to well-sorted, fine- to coarse-grained sandstone with planar and trough cross-stratification with frequent reactivation surfaces and/or mud drapes

S1 Well-sorted, cross laminated-sandstone, locally with highly undulating set boundaries and internal reactivation surfaces/mud drapes

$\mathrm{Sb} \quad$ Bioturbated sandstone

$\mathrm{Sp} \quad$ Moderate to well-sorted, fine to coarse-grained sandstone with parallel lamination

Sw/f Well-sorted, fine- to medium-grained massive or cross-laminated sandstone interbedded with mudstone forming wavy and flaser lamination

$\mathrm{Sm} \quad$ Moderate to well-sorted, very fine- to medium-grained massive sandstone

Migration of straight- and sinuous-crested bedforms under unidirectional or variable lower flow regime with unidirectional and oscillatory motion (with a much greater contribution of the first relative to facies $\mathrm{Sw}$ ) Migration of straight- and sinuous-crested bedforms (ripple scale) under unidirectional or variable lowest flow regime with unidirectional and oscillatory motion

Loss of structure due to intense sediment deformation by biogenic reworking Sand deposition under upper plane bed conditions

Alternating mud deposition from suspension and bedload deposition under fluctuating flow energy

Rapid deposition, with no time for stratification of the sediments or post depositional destruction of the framework due to instabilities in the depositional setting

Sd Moderate to well sorted, very fine- to medium-grained sandstone with soft sediment deformation including convolute folds and over-steep cross-strata.

Am Massive, very fine-grained mudstone

Soft sediment deformation caused by water escape attributed to deposition at high sedimentation rates

Rapid accumulation in areas with high mud supply, soft sediment deformation

Al Laminated mudstone 
Table 2

Summary of the main characteristics of facies associations in the study area, with the interpreted depositional settings

\begin{tabular}{lll}
\hline $\begin{array}{l}\text { Facies } \\
\text { association }\end{array}$ & Description & $\begin{array}{l}\text { Depositional } \\
\text { environment }\end{array}$ \\
\hline A & Well-sorted, fine- to medium-grained sandstone bodies occurring as tabular, slightly undulating & Upper shoreface
\end{tabular}

A Well-sorted, fine- to medium-grained sandstone bodies occurring as tabular, slightly undulating packages internally displaying a variety of undulating structures formed by combined storm flows (i.e., facies Sw, Sqp, and Su). Tabular and trough cross-stratified sandstones (facies Sx), cross-laminated sandstones (facies $\mathrm{Sl}$ ) and hummocky cross-stratified sandstones (facies $\mathrm{Sh}$ ) are locally present. Wave erosion is common. Degree of bioturbation may be very high, with main trace fossils including Thalassinoides, Planolites and Diplocraterion.

Tabular, well-sorted, medium to coarse-grained sandstone with planar and trough cross lamination/stratification (facies Sx), as well as wavy/flaser (facies Sw/f) and parallel lamination (facies Sp). Cross sets display internal reactivation surfaces with mud drapes separating foreset packages, and boundaries that are highly undulating. Opposed-dipping cross sets are locally present. Bioturbated sandstones (facies $\mathrm{Sb}$ ), in which Thalassinoides are widespread, either as isolated burrows or complex networks of interconnecting branches associated with Ophiomorpha, Planolites, Taenidium barretti, and rare Scoyenia.

Moderate to well-sorted, very fine- to medium-grained, massive (facies Sm) or soft sediment deformed sandstones (facies Sd). Locally present are trough/tabular cross-stratified sandstone (facies Sx), swaley cross-stratification (facies Ss) and quasi-planar lamination (facies Sqp). The sandstones display lobate geometry, and are internally characterized by coarsening upward cycles. Lobes show depositional dip to the west/northwest and bi-directional flows pointing to the northwest and southeast. Reactivation surfaces and mud drapes are abundant within cross sets, as are combined flow laminations. Taenidium barretti, Planolites, occasional Thalassinoides and Diplocraterion occur.

D Alternation of massive, very fine-grained sandstones (facies Am) and laminated mudstones (facies $\mathrm{Al}$ ) forming either fining or coarsening upward cycles. Fining upward cycles form slightly undulating beds with frequent internal truncation, locally forming swaley and hummocky cross stratification (facies $\mathrm{Sw}$ and $\mathrm{Sh}$ ) that grade into quasi-planar lamination (facies Spq). Extremely bioturbated, but hard to identify individual traces, except for possible Diplocraterion (?)

Fig. 2C, D) or, less commonly, swaley cross-stratification (facies Sw; Fig. 2G), both of which become laterally undulating, forming quasi-planar laminations (facies Sqp; Fig. 2C-F). Small-scale, hummocky cross-stratification, inserted in facis $\mathrm{Sw}$, is only locally observed (Fig. 2E, F). Laterally, these facies grade into sandstones with small scale cross-stratification (facies $\mathrm{Sx}$ ) and cross-lamination (facies Sl) displaying undulating lower set boundaries and also abundant internal reactivation surfaces, locally with mud drapes (Fig. $2 \mathrm{H}$ ). The undulating sandstones are locally cut by broad, shallow scours that are up to $5 \mathrm{~m}$ deep and several tens of metres wide that are filled by sandstones also showing undulating stratification as described above.

Interbedded with the stratified sandstones are highly bioturbated sandstones (facies $\mathrm{Sb}$ ) that are fine-grained and wellsorted. The bioturbation is so intense that primary physical structures are not recognizable. Despite the intensity, there is a dominance of Thalassinoides, Diplocraterion (Fig. 3A, B) and Planolites traces. Two different classes of Thalassinoides burrow system may be distinguished by the average diameter of the galleries: smaller $(7 \mathrm{~mm})$, and larger $(16 \mathrm{~mm})$.

Measurements of azimuth dips of the cross-stratified sandstones reveal bi-directional flows orientated to either the northwest or the southeast (Fig. 3C).

\subsection{Facies association $B$}

This facies association is frequent at the base of the sections, forming laterally continuous, tabular sandstone beds that are up to $1.5 \mathrm{~m}$ thick and may show slightly undulating, locally erosional tops. It grades both laterally and vertically into facies association $\mathrm{A}$, from which it is distinguished by 

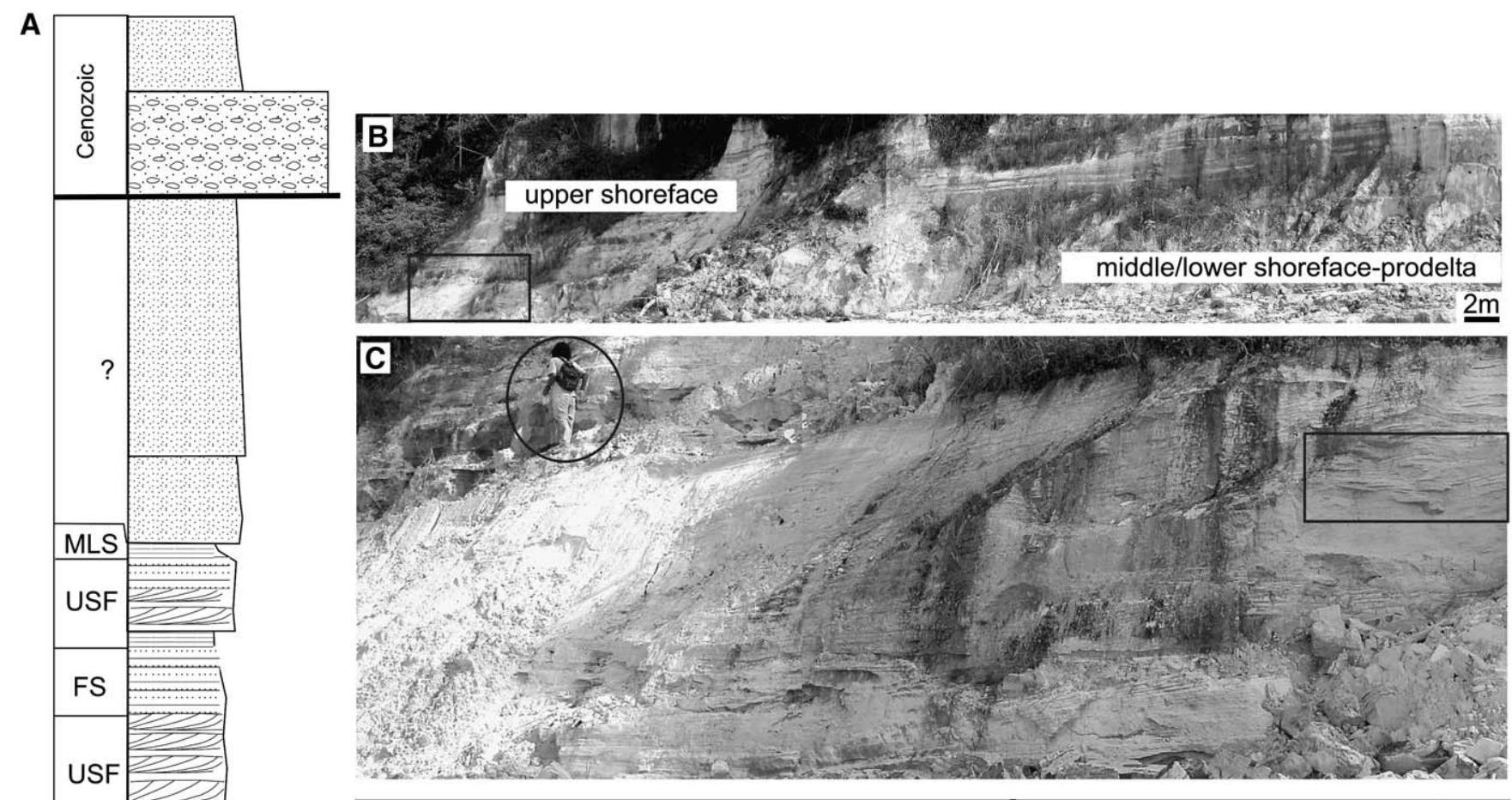

\section{D}
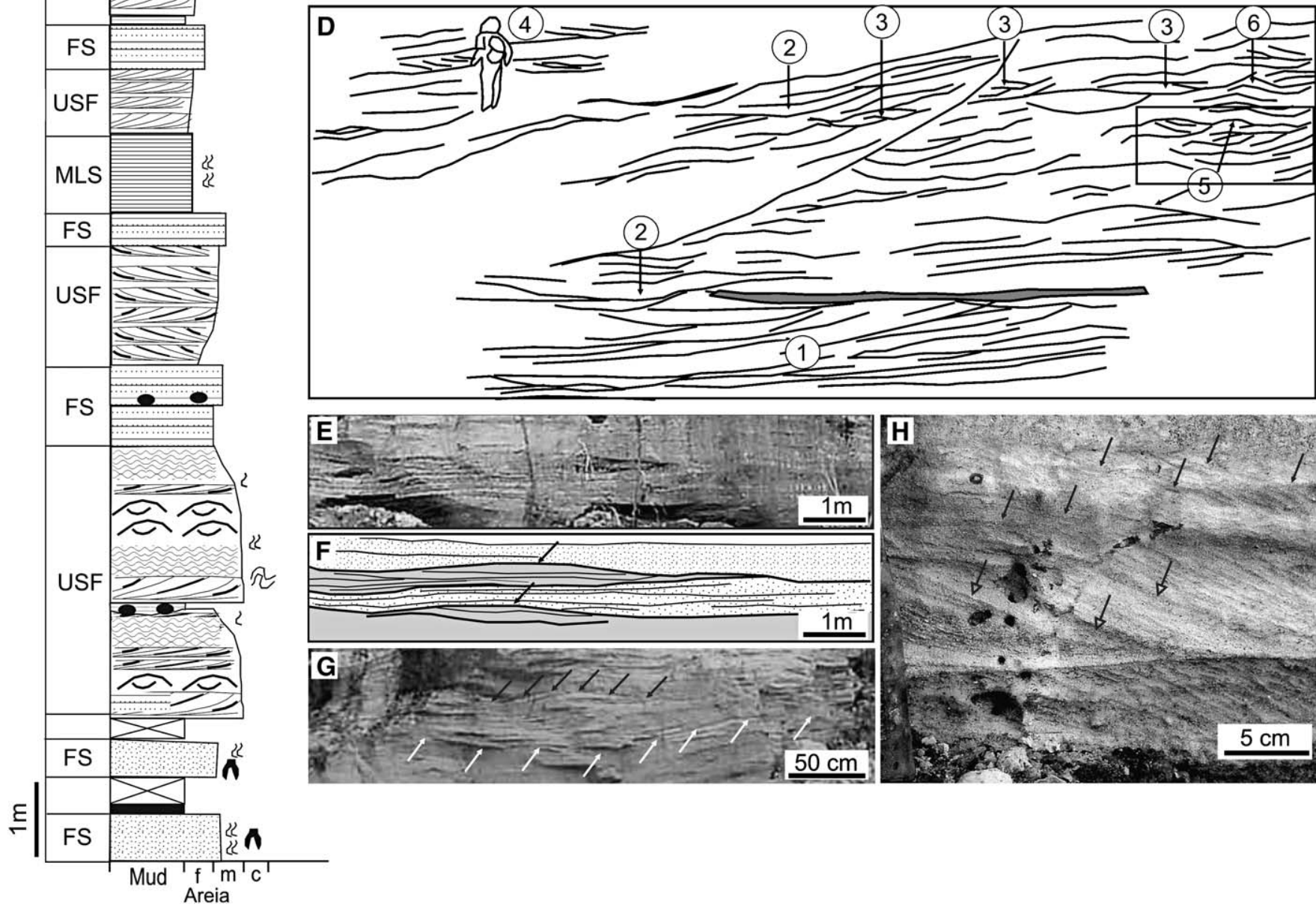
571

602 the coarser grain size, forming thickening-upward successions. 603 The sandstones are well sorted and, in general, fine- to 604 medium-grained, though beds with coarse grain sizes are 605 also frequent, in which case quartz granules and mud clasts 606 are dispersed. Five sedimentary facies occur in this associa607 tion, including, in order of abundance, bioturbated sandstone $608(\mathrm{Sb})$, planar and trough cross-laminated and cross-stratified 609 sandstone (facies S1 and Sx, respectively), wavy/flaser lami610 nated sandstone (facies Sw/f), and parallel-laminated sand611 stone (facies Sp). Facies S1 and Sx display mud drapes 612 (Fig. 4A), undulating set boundaries and internal reactivation 613 surfaces (Fig. 4B), as described in the other facies associa614 tions. Opposed-dipping cross sets are locally present. The 615 sandstones in facies Sw/f are either massive or incipiently 616 cross-laminated and display frequent symmetrical scours high617 lighted by mud layers (Fig. 4C).

618 A typical feature of all facies in this association is the vari619 able degree of bioturbation, which can be very intense, as in 620 facies Sb. Most of the deposits are reworked by the abundant, 621 but monospecific Thalassinoides suite (Fig. 4D, E), which oc622 cur either as isolated burrows or as complex networks of inter623 connecting branches. Occasional Ophiomorpha may also be 624 present (Fig. 4F). Taenidium barretti (Fig. 4H), Planolites 625 (Fig. 4G), and rare Scoyenia (Fig. 4I), define the Taenidium 626 barretti suite, overprinted by (Fig. 4H) or interbedded with 627 (Fig. 4G) the Thalassinoides suite.

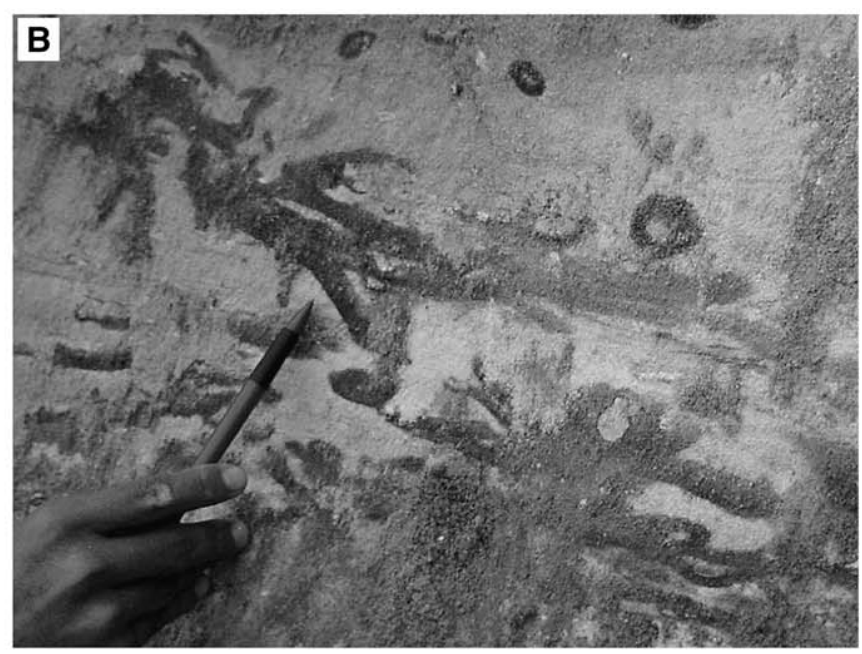

C

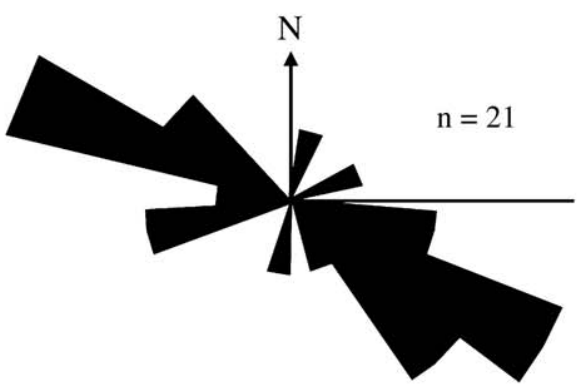

628

These deposits are characterized by well-sorted, very fineto medium-grained sandstones, typically displaying a lobate geometry (Fig. 5A-C). Individual lobes are, in general, less than $2 \mathrm{~m}$ thick and up to $60 \mathrm{~m}$ long, and they may show an overall westward/northwestward depositional dip.

The sandstones are internally organized into coarseningupward successions (Fig. 5A), as revealed by an inverse grading from very fine- to medium-grained sands or by a downward transition into massive mudstones. Where exposures allowed sufficient observation, the sandstone lobes were seen to be amalgamated, forming thicker sandy nuclei, which become laterally subdivided into several smaller lobes defined by thin (a few $\mathrm{cm}$ ) argillite beds. Within an individual nucleus, the sandstones are either massive (facies $\mathrm{Sm}$ ) or display soft sediment deformation (facies Sd; Fig. 5G), characterized mostly by convolute folds and over-steep cross-strata. Towards the margins, where the lobes are better defined, the sandstones are typically well-stratified, showing medium-scale (sets $0.2-0.3 \mathrm{~cm}$ thick, exceptionally $0.5 \mathrm{~m}$ thick) trough/tabular (Fig. 5D, E) and, less commonly, swaley cross stratification (facies Sx and Sw, respectively). Occurring with these structures at the lobe bases and edges are abundant tabular and trough cross-laminations (facies Sl). Palaeocurrent directions obtained from these strata record a wide
661

662

663

664

665

666

667

668

669

670

671

672

673

674

675

676

677

678

679

680

681

682

683

684 

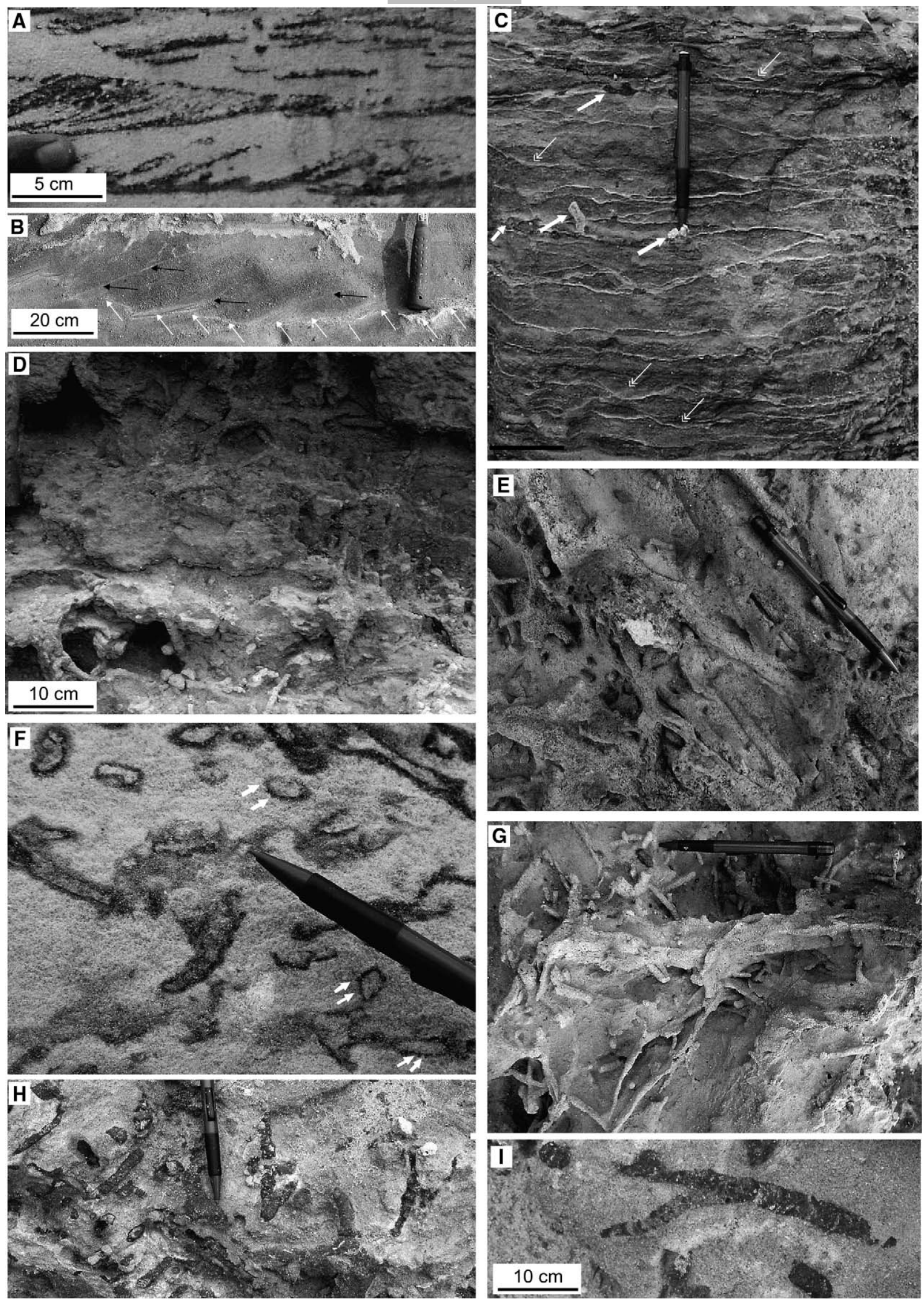

Fig. 4. Foreshore deposits (facies association D). A, low angle cross-lamination mantled by mud drapes. B, small-scale cross-stratification displaying undulating lower boundaries (white arrows) and internal reactivation surfaces locally with mud drapes (black arrows). C, wavy to flaser (light, undulating laminae) heterolithic sandstones typical of this facies association (white arrows with single head indicate trace fossils; those with double head indicate symmetrical scours); crenulated appearance of mud layers is due to presence of diminutive ripple marks (black arrows). D, E, branched traces of Thallasinoides in profile and plan views respectively. F, Ophiomorpha; white arrows indicate pellets surrounding trace walls. G, a mixture of Planolites and Taenidium barretti. H, Taenidium barretti. I, Scoyenia. Pen is $15 \mathrm{~cm}$ long.

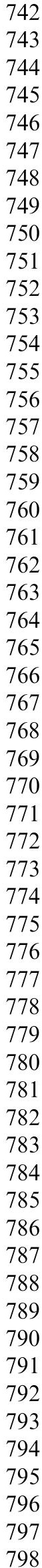


799

800

801

802

803

804

805

806

807

808

809

810

811

812

813

814

815

816

817

818

819

820

821

822

823

824

825

826

827

828

829

830

831

832

833

834

835

836

837

838

839

840

841

842

843

844

845

846

847

848

849 Fig. 5. Delta mouth bar deposits (facies association A). A-C, lobate geometry; note the typical coarsening upward successions in A, and the amalgamation of
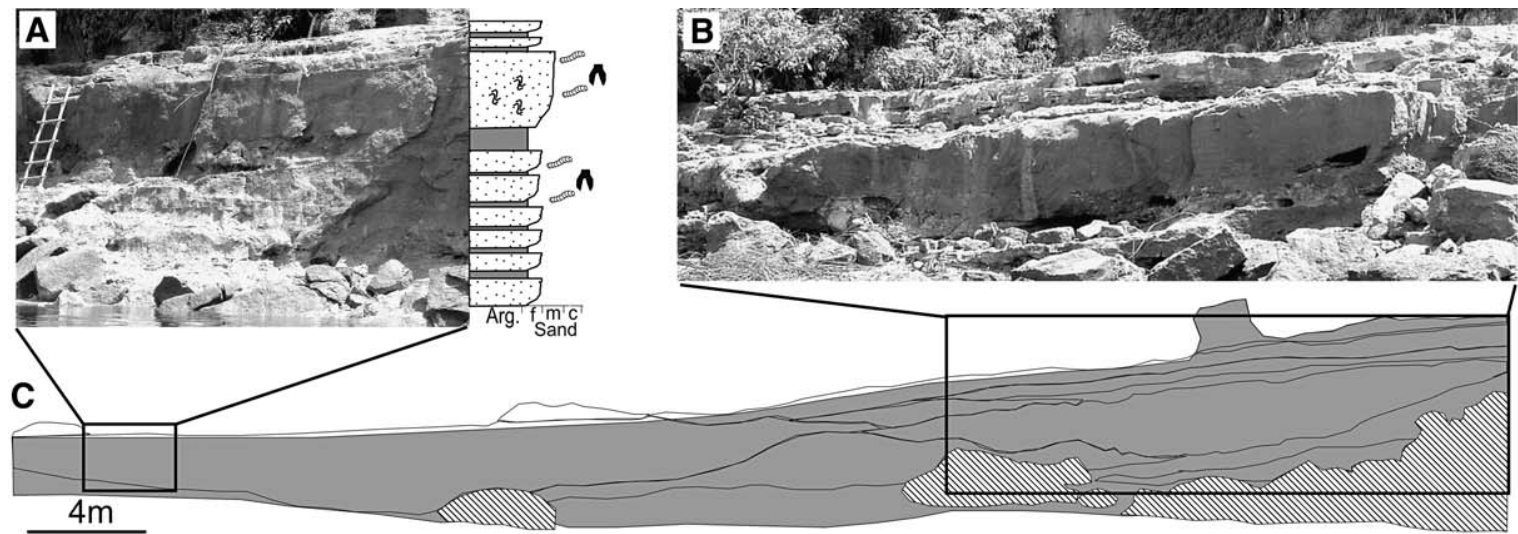

Deltaic sandstone lobes (facies association A) 正 Soft sediment deformation Prodeltaic mudstone (facies association B) Not exposed
Taenidium

n Thalassinoides
856

857

858

859

860

861

862

863

864

865

866

867

868

869

870

871

872

873

874

875

876

877

878

879

880

881

882

883

884

885

886

887

888

889

890

891

892

893

894

895

896

897

898

899

900

901

902

903

904

905

906

907

908

909

910

911

912 
distribution of the flow, but with a mainly southeast-orientated mode (Fig. 5E).

A typical feature of the cross-sets is the presence of frequent reactivation surfaces mantled with mud drapes, as observed in the cross-sets of the other facies associations. In medium-scale cross-sets, these surfaces define foreset packages averaging $5-10 \mathrm{~cm}$ thick. The lower set boundaries of both mediumand small-scale strata are undulating, forming broad, shallow scours. Cross-lamination structures with highly undulating lower set boundaries and abundant reactivation surfaces may (Fig. 5F); in these cases, wavy-cut erosional scours are frequent.

The top of the beds or even the entire beds may be bioturbated, forming facies $\mathrm{Sb}$ (bioturbated sandstones). Recognizable trace fossils characterize an assemblage dominated by Taenidium barretti and Planolites. (Fig. 6A, B) and occasional, but locally abundant, small, flattened Thalassinoides galleries (Fig. 6A). Beds with a Diplocraterion ichnofabric are also observed (Fig. 6C, D). The ichnofabric is entirely dominated by horizontally-sectioned U-burrows with vertical spreiten, many revealing the curved end of the burrows. Burrow boundaries are invariably sharp-walled, suggesting colonization of firmgrounds (Pemberton and Frey, 1985; Bromley, 1996; Buatois et al., 2001).

\subsection{Facies association D}

This association forms units up to $3 \mathrm{~m}$ thick and includes fine-grained facies, consisting mostly of argillites, and very have evolved from quasi-planar laminations (facies Sqp) fine- to fine-grained sandstones. The strata form tabular to slightly undulating beds up to $0.2-0.3 \mathrm{~m}$ thick, which are interbedded with facies association A (Fig. 2A) or C (Fig. 5AC). Internally, the lithologies are arranged into either cycles of sandstones that grade upward into mudstones or mudstones that grade up into sandstones. The mudstones display red to light brown colors, are mostly silty, and are either laminated (Al) or massive (Am). Laminated mudstones are interbedded with white or yellow, very-fine grained sandstones showing parallel and low-angle, quasi-planar laminations (Facies Sp). In these cases, the beds are undulating and display bases and tops that are slightly concave and convex, respectively, forming swaley and, locally, hummocky cross-stratification (facies $\mathrm{Sw}$ ). Massive silty mudstones locally may show wavy, erosional surfaces superposed by successive smaller-scale scours (up to only few $\mathrm{cm}$ wide). The degree of bioturbation might be very high in the massive muddy lithologies, but individual traces could not be identified, except for spreiten-like, subvertical traces resembling Diplocraterion (?). Some beds, though, are only locally bioturbated.

\section{Interpretation of sedimentary processes}

Deposition by highly oscillatory flows is revealed by the dominance of different styles of cross-strata characterized by undulating lower set boundaries and abundant internal reactivation surfaces with mud drapes. Bi-directional flows, as indicated by palaeocurrent data, are also compatible with this interpretation. Two possibilities are currently considered here
970

971

972

973

974

975

976

977

978

979

980

981

982

983

Thalassinoides (Th) and Taenidium barretti (Te). B, detail of Taenidium barretti. C, a view of the top of a sand bed with abundant Diplocraterion. D, detail of Diplicraterion from the surface shown in C. All figures show the trace fossils in plan view. 
1027 as the most likely causes: tidal currents and waves. Reactiva1028 tion surfaces and mud drapes separating foreset packages are 1029 commonly recorded in association with tidal currents (Mow1030 bray and Visser, 1984; Chakraborty and Bose, 1990; Simpson 1031 and Eriksson, 1991). However, several workers have claimed 1032 that similar features might be also due to wave action (e.g., 1033 Raaf et al., 1977; Arnott, 1992). In fact, differentiating be1034 tween these processes in the geological record can be highly 1035 problematic, particularly in cases where there is a mixture of 1036 tidal and wave processes (e.g. Johnson and Baldwin, 1986; 1037 Harris and Eriksson, 1990; Amos et al., 1995; Colquhoun, 1038 1995).

1039 Interpreting the sedimentary signature of tidal currents is 1040 facilitated only when reactivation surfaces/mud drapes form 1041 a succession of alternating thicker and thinner foreset bundles 1042 that can be related to diurnal and monthly tidal periodicities 1043 (e.g. Allen, 1968; Yang and Nio, 1985; Kreisa and Moiola, 1044 1986; Koster et al., 1987; Leckie and Singh, 1991). These fea1045 tures were not observed in the study area, but this absence can1046 not be used to preclude a tidal influence, as many ancient 1047 deposits attributed to tidal processes throughout the world do 1048 not show such diagnostic structure, even in subtidal settings 1049 where development of tidal bundles are more likely (Clifton, 1050 1983; Yang and Nio, 1985; Koster et al., 1987).

1051 Thus, although a tidal influence cannot be completely ruled 1052 out in this instance, the association of sedimentary features fa1053 vours a wave-dominated influenced environment. This is sug1054 gested by the abundance of highly undulating structures, 1055 including swaley cross-stratification, with locally associated 1056 hummocky cross-stratification, and quasi-planar lamination. 1057 These features are considered typical of either oscillatory or 1058 combined flows with varying dominance of the unidirectional 1059 and orbital components. In particular, swaley cross-stratification 1060 indicates the action of larger than fair-weather waves, sug1061 gesting a storm-influenced setting (e.g., Allen and Pound, 1062 1985; McCrory and Walker, 1986; Plint and Walker, 1987; 1063 Duke and Prave, 1991; Plint and Norris, 1991; Hadley and 1064 Elliot, 1993). This structure records the migration of low re1065 lief bedforms under storm-generated, combined flows (e.g., 1066 McCrory and Walker, 1986). The gradation from swaley 1067 cross-stratification to quasi-planar lamination and, locally, 1068 hummocky cross-stratification, is predicted in phase diagrams 1069 of combined flows, attesting to constant changes in the inten1070 sity of the unidirectional and oscillatory components (e.g., 1071 Nøttvedt and Kreisa, 1987; Arnott, 1992).

1072 Considering this interpretation, the cross-sets displaying 1073 abundant reactivation surfaces and mud drapes are interpreted 1074 here to be more likely related to wave action than to tidal cur1075 rents. These features are attributed to complex, short-term ori1076 entations of the flow and have been recorded in association 1077 with combined flows in many other storm settings (e.g., Swift 1078 et al., 1983; Nøttvedt and Kreisa, 1987; Arnott and Southard, 1079 1990). The quasi-planar lamination may have formed during 1080 periods of upper flow regime and when the oscillatory motion 1081 was stronger than the unidirectional one (Arnott, 1992). Coex1082 isting asymmetrical and symmetrical scours are also consistent 1083 with combined flows. In particular, cross-sets with reactivation surfaces and highly undulating lower boundaries are features of combined flow bedforms (e.g., Raaf et al., 1977). In this instance, the gradation of these structures from quasi-planar laminations records laterally decreasing flow energy.

The fact that the interbedded sandstone and argillite layers are not in sharp contact, as expected in tidal deposits (e.g. Visser, 1980), but rather grade vertically, is taken as further evidence in support of wave action in the study area, with the grading being attributed to waning energy flows associated with the passage of storms. The upward transition from large-scale, low-angle dipping strata to swaley and combined flow cross-strata is consistent with this process. Similar features have been observed in association with upper shoreface Cretaceous deposits in the São Luís-Grajaú Basin (e.g. Rossetti, 1997; Rossetti et al., 2000).

\section{Discussion of the depositional settings}

The sedimentological and ichnological data do not support the presence of continental palaeoenvironments in the Alter do Chão Formation as exposed in the study area. As discussed above, the set of sedimentary facies points to the prevalence of wave processes which, in association with the ichnological attributes, suggest deposition in environments not far from a shoreline and under the influence of significant wave (i.e., storm) action.

Although waves do form in some continental settings, such as in lakes and, locally, at the confluence of fluvial channels, the wave-influenced deposits exposed in the study area cannot be related to purely continental settings. This conclusion is based on the dominance of both wave-influenced sedimentary structures and of a Thalassinoides trace-fossil suite.

Thalassinoides is perhaps the most common burrow in ancient shallow marine and marginal marine environments, inhabiting dominantly silty-sandy substrates (Pemberton et al., 1992a, 2001). These burrows are assumed to have been produced by opportunistic, deposit-feeding thalassinidean crustaceans in post-Paleozoic rocks and by their ancestors, or by a crustacean with similar behaviour, in Paleozoic rocks (Sheenan and Schiefelbein, 1984; Watkins and Coorough, 1997; Ekdale and Bromley, 2003). By comparison, modern galleries similar to Thalassinoides are produced by thalassinidean shrimps that never abandon their burrows, growing-up inside and enlarging the burrow system, being the most common burrowing organisms of marine intertidal and shallow subtidal environments (Griffis and Suchanek, 1991). Although rare, Thalassinoides is also found in deep marine environments (Sheenan and Schiefelbein, 1984; Uchman, 1995; Buatois et al., 2001). Its facies-crossing character is a consequence of the opportunistic behaviour of a tracemaker able to support episodic or constant environmental changes (Wightman et al., 1987; Pemberton and Wightman, 1992). Although the geological record of Thalassinoides is overwhelmingly restricted to marine and brackish-water successions, there is one exception: Shukla et al. (2002) reported the presence of Thalassinoides in Quaternary deltaic and fluvial silt and sand deposits, apparently without marine influence. The only organisms that can produce 
similar burrows in continental settings are crabs, but in this case the galleries differ from those described here because they are much simpler, shallower and with fewer branches. Thus, the occurrence of Thalassinoides in the sedimentary record supports the inference of a depositional setting under the influence of marine processes. Thalassinoides became particularly widespread from the Mesozoic onwards, when their burrow systems were large and became more complex, forming mazes and boxworks (Frey, 1975; Bromley, 1996).

The complex arrangement of Thalassinoides burrows observed in facies association A, including burrow systems of different sizes, probably represents colonization by two major classes of individuals in a single population, revealing juvenile recruitment. This population strategy is common in brackishwater settings as a response to daily changes in controlling ecologic parameters dominated by extreme salinity fluctuations. Benthic communities of substrates affected by frequent salinity fluctuations, as occur in brackish-water systems, tend to consist of opportunistic elements with prevalent dwelling and feeding strategies (Ekdale et al., 1984; Pemberton and Wightman, 1992; Beynon and Pemberton, 1992; Pemberton et al., 1992b, 2001; Buatois et al., 1998; Gingras et al., 1999). The large burrows and reduced-size galleries of Thalassinoides in the same horizon, as recorded in this facies association, are thus comparable to brackish-water ichnofaunas (Wightman et al., 1987; Pemberton and Wightman, 1992; Pemberton et al., 2001; Buatois et al., 2005).

The highly bioturbated, monospecific Thalassinoides suite, as recorded particularly in facies association $\mathrm{B}$, is consistent with this proposed depositional setting. Intense bioturbation Thalassinoides networks are expected to develop in moderate to low energy, shallow-marine to marginal-marine environments affected by occasional salinity fluctuations (stenohaline to polyhaline: Pemberton et al., 2001; Netto and Rossetti, 2003). In addition to the Thalassinoides suite, the presence of Diplocraterion in the deposits studied supports the influence of marine conditions, recording periods with a dominance of saline waters. On the other hand, the Taenidium barretti trace fossil in facies associations $\mathrm{B}$ and $\mathrm{C}$ attests to periods of predominantly freshwater influence, as this ichnospecies is

characteristic of freshwater conditions (Buatois et al., 1998, 2002; Netto and Rossetti, 2003). When the salinity gradient reaches freshwater levels, a physiological barrier is erected to marine organisms and even those capable of enduring strong salinity fluctuations, such as the deep-burrowing Thalassinoidesproducers, cannot survive. The successive alternation of Taenidium barretti with Thalassinoides in facies association B suggests relatively high salinity during coastal evolution, which is also compatible with the attribution of these deposits to foreshore settings (Fig. 7), as proposed in the following section.

Scarce, small and flattened Thalassinoides burrows, as occur in facies association $\mathrm{C}$, are also good representatives of meso- to oligohaline waters in brackish-water settings (Pemberton et al., 2001; Netto and Rossetti, 2003; Buatois et al., 2005). However, the dominance of Taenidium barretti with only a few Thalassinoides in this facies association indicates a prevalence of freshwater to subaerial substrates (Scoyenia Ichnofacies: Pemberton and Frey, 1985; Buatois et al., 1998, 2002; Buatois and Mángano, 2004). The sharp-walled burrow boundaries of Diplocraterion observed in facies association C suggest colonization of firmgrounds and testify to substrate exhumation and temporary exposure before the next marine ingression (MacEachern et al., 1992; Pemberton et al., 2001; Netto and Rossetti, 2003).

A marine influx, probably resulting from storm events, would have brought in an opportunistic marine fauna, represented by the Thalassinoides-dominated ichnofauna, which rapidly colonized the substrate. Considering the very low trace fossil diversity and the mixed occurrence of saline and freshwater traces, it is suggested that deposition took place in environments experiencing a mixture of saline and freshwater flows, which are typical of brackish-water environments. In fact, it is common to observe the Thalassinoides suite crosscutting substrates previously occupied by the TaenidiumPlanolites suite, and vice-versa (Fig. 7).

The lack or scarcity of bioturbation in the strata with abundant sedimentary structures formed by wave action in the study area is to be expected, as the density of bioturbation varies from high in quiet, protected settings to rare in highenergy settings. Therefore, information from physical and

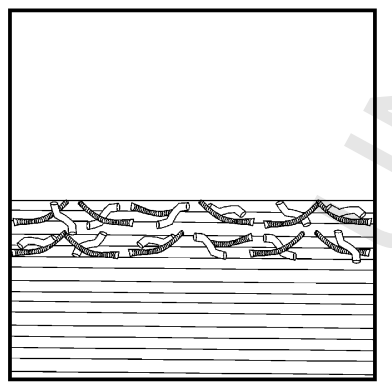

pre-storm colonization freshwater

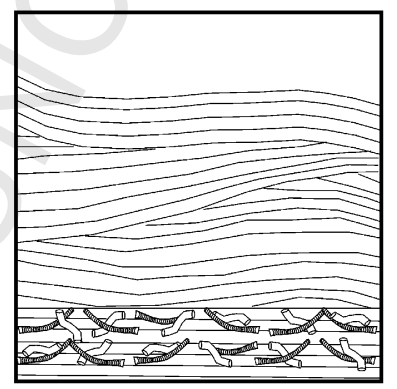

storm event

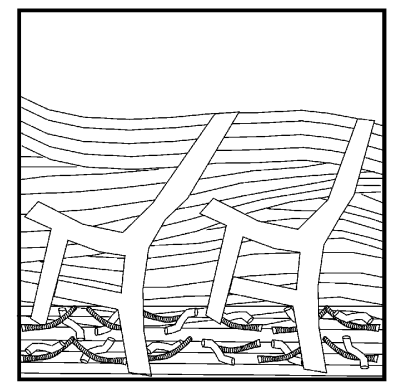

post-storm opportunistic colonization marine/ brackish water

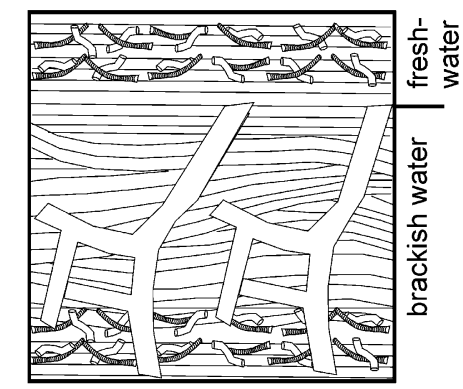

post-storm resident colonization when freshwater condition returns
1198

1199

1200

1201

1202

1203

1204

1205

1206

1207

1208

1209

1210

1211

1212

1213

1214

1215

1216

1217

1218

1219

1220

1221

1222

1223

1224

1225

1226

1227

1228

1229

1230

1231

1232

1233

1234

1235

1236

1237

Fig. 7. Schematic diagram showing pre- and post-event colonization controlled by storm events in the Alter do Chão Formation. 


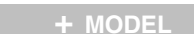

biogenic structures are complementary, and indicate the presence of depositional environments exposed to strong wave action during storms laterally coexisting with more protected settings.

Considering the limited lateral extend of the studied transect (only up to $15 \mathrm{~km}$ in length), reconstructing the depositional system is difficult. However, our suggested ichnological interpretation of mixed (i.e., freshwater and marine) water inflows conforms to a setting located in the transitional marine realm. The four facies associations conform to storm-influenced deltaic environments. A deltaic setting is particularly suggested by facies association $\mathrm{C}$, which contains well-developed progradings and lobes indicative of deposition accompanying a rapid loss in energy related to the entrance of flows into a standing body of water, a process typical of distributary mouth bars. Massive and deformed sandstones in this association are consistent with a setting with a high sand inflow and gravity instability (e.g., Coleman, 1988; Orton and Reading, 1993; Glover and O'Beirne, 1994). Mouth bars deposits are characterized by high interstitial water pressure, which leads to intense fluidization and liquefaction, (e.g., Mills, 1983; Elliott, 1986; van Loon and Brodzikowski, 1987; Coleman, 1988), processes that produced the massive and deformed sandstones (facies Sm and $\mathrm{Sd}$ ). In addition, mouth bars are places characterized by intense gravity instabilities promoted by the overloading of sands on muds (Shepard, 1955; Coleman and Prior, 1983; Elliott, 1986; Coleman, 1988). Mouth bars of many modern and ancient deltaic settings display such features (e.g., Nemec et al., 1988; Edwards, 1995). The small size of the sand lobes developed in the study area may be explained in the context of delta lobes entering shallow waters.

Two depositional models may be invoked to explain the strata studied: a wave-dominated delta and a wave-dominated estuary. The prevalence of brackish-water conditions favours an estuarine interpretation. Tidal channel deposits, however, which typify estuarine complexes, were not recognized in the study area. Furthermore, tidal currents are the main agents responsible for sediment deposition within estuaries, even in wave-dominated ones (e.g., Dalrymple et al., 1992), but the study area bears no conclusive evidence for tidal sedimentation.

Although an estuarine interpretation cannot be completely ruled out, the absence of criteria in support of tidal sedimentation, added to the abundance of sedimentary structures attributed to both fair-weather and storm waves, leads us to propose that a wave-dominated deltaic setting is more likely (Fig. 8). Like estuarine settings, wave-dominated deltas are characterized by a mixture of fluvial and marine inflows, thus stressed environments with brackish water conditions may develop.

Facies association D records the muddiest and therefore the lowest energy depositional setting of the study area. When these deposits occur interfingering with facies association C, they are interpreted as prodeltaic sediments. However, a large proportion of these deposits is genetically connected with facies associations $\mathrm{A}$ and $\mathrm{B}$, when they are attributed to lower/ middle shoreface settings. This interpretation is consistent with the presence of undulating sedimentary structures dominated by storm wave action. These structures suggest a low 
energy setting located below the fair-weather wave base but periodically affected by storm waves, favourable for preservation of hummocky cross-stratification (e.g. Walker, 1984; McCrory and Walker, 1986; Nøttvedt and Kreisa, 1987; Cheel and Leckie, 1993) and for intense biogenic reworking. Deposits of this facies association with scarce bioturbation probably record sedimentation in areas still under the effect of storm waves.

The spatial transition from facies association D to A and B further supports the above interpretation. Facies association A is also dominated by undulating structures, mostly represented by swaley cross-stratification. This structure is formed in a high energy environment above the storm wave base and close to the fair-weather wave transition, which within the proposed environmental context, is probably representative of the upper shoreface, as recorded in many other similar settings (Dott and Bourgeois, 1982; Walker, 1984; Allen and Pound, 1985; McCrory and Walker, 1986; Plint and Walker, 1987; Duke and Prave, 1991; Plint and Norris, 1991; Hadley and Elliot, 1993). The amalgamated nature of the sandstones bodies in facies association A is consistent with an upper shoreface setting, where erosion is frequent (Dott and Bourgeois, 1982; Brenchley et al., 1986).

The dominance of fair-weather wave structures in facies association B indicates deposition above fair-weather wave base, characterizing a shallower environment than indicated by facies associations $\mathrm{A}$ and $\mathrm{D}$, being attributed to foreshore settings (e.g., Clifton et al., 1971; Driese et al., 1991). Thus, any deposits formed by storm action were subsequently reworked by fair-weather waves between storms. The abundance of fairweather wave structures in these strata, as well as the presence of parallel lamination that might record beach face deposition, is consistent with this interpretation. Fair-weather conditions contributed to the widespread development of Thalassinoides, which reached their greatest abundance in these deposits. In this context, Thalassinoides represents the opportunistic post-storm colonization (Pemberton et al., 1992c, 2001), subsisting in the substrate while the salinity values permitted (oligohaline waters: see Wignall, 1991; Netto and Rossetti, 2003). The Taenidium-Planolites suite is a relict of the original resident non-marine endofauna, characterizing pre-storm colonization, when freshwater conditions apparently prevailed (Fig. 7). The fact that facies association B overlies upper shoreface strata, forming coarsening-upward successions, in addition to its coarser-grained nature relative to those deposits, further supports a setting located closer to the coastline, adjacent to the shoreface.

Unfortunately, our palaeocurrent data are too few to provide a reliable determination of flow pattern. However, it is possible to infer a coast orientated roughly in a northeastsouthwest direction and a continental influx from the northwest, as suggested by the main southeastward mode recorded from delta lobe deposits. This coastline would have been affected by storm waves oscillating between northwest and southeast. Marine conditions might, therefore, have prevailed to the east or southeast of the study area. If this is correct, then correlatable deposits located in those areas should record increased evidence of marine influence, a hypothesis that must be tested in future investigations.

\section{Conclusion}

The traditional view that the Cretaceous deposits of the intracratonic Amazonas Basin are entirely continental in nature might be a result of a lack of detailed sedimentological studies. The sedimentological and ichnological data presented herein suggest that, after the Permo-Carboniferous marine incursion that gave rise to the Itaituba limestones, the Amazonas Basin might also have experienced a marine incursion during the Cretaceous. The magnitude of this transgression and the route by which marine waters entered the basin are issues that need to be discussed in the light of a much larger volume of information. However, the data available from our study allow us to suggest a palaeoenvironmental model in which continental flows from the northwest formed a wave-dominated delta system that prograded into a basin connected to the marine realm to the east or southeast. This model must be tested by further investigations of deposits of the Alter do Chão Formation in the central and eastern areas of the Amazonas Basin. Despite the limited potential for the recovery of fossils, given the red-bed nature of the formation, it is necessary to search for localities that might yield microfossils in order to improve the depositional model.

\section{Uncited references}

Buatois et al., in press

\section{Acknowledgments}

This work was financed by IBAMA-PNUD BRA/00/008 through the Strategic Study "Scientific Bases for the Conservation of the Várzea: Identification and Characterization of Biogeographic Regions" (PROVARZEA/MPEG/FADESP). We thank Antonio Emídio Santos Jr. for assistance and companionship, as well as Ana Albernaz and Luís Mangabeira for encouragement and logistic support during our fieldwork. We are also grateful to the referees, J.R. Ineson and A. Ruffell, for their helpful comments on the original manuscript, and D.J. Batten for his editorial work.

\section{References}

Allen, J.R.L., 1968. Current Ripples and their Relation to Patterns of Water Flow and Sediment Motion. North-Holland, Amsterdam, xxx pp.

Allen, P.A., Pound, C.J., 1985. Storm sedimentation. Journal of the Geological Society, London 142, 411-412.

Amos, C.L., Barrie, J.V., Judge, J.T., 1995. Storm-enhanced sand transport in a macrotidal setting, Queen Charlotte Islands, British Columbia, Canada. In: Flemming, B.W., Bartholomä, A. (Eds.), Tidal Signature in Modern and Ancient Sediments. International Association of Sedimentologists, Special Publication 24, 53-70.

Amos, C.L., Li, M.Z., Choung, K.S., 1996. Storm-generated, hummocky stratification on the outer-Scotian Shelf. Geo-Marine Letters 16, 85-94. 
Arnott, R.W.C., 1992. Ripple cross-stratification in swaley cross-stratified sandstones of the Chungo Member, Mount Yamnuska, Alberta. Canadian Journal of Earth Sciences 29, 1802-1805.

Arnott, R.W.C., 1993. Quasi-planar-laminated sandstone beds of the Lower Cretaceous Bootlegger Member, north-central Montana: evidence of combined-flow sedimentation. Journal of Sedimentary Research 63, 488-494.

Arnott, R.W.C., Southard, F.J.B., 1990. Exploratory flow-duct experiments on combined flow bed configurations, and some implications for interpreting storm-event stratification. Journal of Sedimentary Petrology 60, 211-219.

Beynon, B.M., Pemberton, S.G., 1992. Ichnological signature of a brackish water deposit: an example from the Lower Cretaceous Grand Rapids Formation, Cold Lake Oil Sands area, Alberta. In: Pemberton, S.G. (Ed.), Applications of Ichnology to Petroleum Exploration: a Core Workshop. Society of Economic Paleontologists and Mineralogists, Core Workshop 17, 99-221.

Boersma, J.R., Terwindt, J.H.J., 1981. Neap-spring tide sequences of internal shoal deposits in a mesotidal estuary. Sedimentology 28, 151-170.

Brenchley, P.J., Romano, M., Gutierrez-Marco, J.C., 1986. Proximal and distal hummocky cross-stratified facies on a wide Ordovician shelf in Iberia. In Knight, R.J., McLean, J.R. (Eds.), Shelf Sands and Sandstones. Canadian Society of Petroleum Geologists. Memoir 2, 241-255.

Bromley, R.G., 1996. Trace fossils. Biology, taphonomy and applications, second ed. Chapman and Hall, London, $361 \mathrm{pp}$.

Buatois, L.A., Mángano, M.G., 2004. Animal-substrate interactions in freshwater environments: applications of ichnology in facies and sequence stratigraphic analysis of fluvio-lacustrine successions. In: McIlroy, D. (Ed.), The Application of Ichnology to Palaeoenvironmental and Stratigraphic Analysis. Geological Society, London, Special Publication 228 , 311-335.

Buatois, L.A., Mángano, M.G., Maples, C.G., Lanier, W.P., 1998. Allostratigraphic and sedimentologic applications of trace fossils to the study of incised estuarine valleys: an example from the Virgilian Tonganixie Sandstone Member of eastern Kansas. Current Research in Earth Sciences 241, $1-27$.

Buatois, L.A., Mángano, M.G., Aceñolaza, F.G., 2002. Trazas fósiles. Museo Egidio Ferruglio, Trelew, Special Publication 1, 382 pp.

Buatois, L.A., Mángano, M.G., Sylvester, Z., 2001. A diverse deep-marine ichnofauna from the Eocene Tarcau Sandstone of the eastern Carpathians, Romania. Ichnos 8, 23-62.

Buatois, L.A., Gingras, M., McEachern, J.A., Mángano, M.G., Zonneveld, J.-P., Pemberton, S.G., Netto, R.G., Martin, A. Colonization of brackishwater systems through time: evidence from the trace-fossil record. Palaios 20 , in press.

Chakraborty, C., Bose, P.K., 1990. Internal structures of sandwaves in a tidestorm interactive system: Proterozoic Lower Quartzite Formation, India. Sedimentary Geology 67, 133-142.

Cheel, R.J., Leckie, D.A., 1993. Hummocky cross-stratification. In: Wright, V.P. (Ed.), Sedimentary Review, 1. Blackwell Scientific Publications, Oxford, pp. 103-122.

Cheel, R.J., Middleton, G.V., 1993. Directional scours on a transgressive surface: examples from the Silurian Whirlpool Sandstone of southern Ontario, Canada. Journal of Sedimentary Petrology 63, 392-397.

Clifton, H.E., 1983. Discrimination between subtidal and intertidal facies in Pleistocene deposits, Willapa Bay, Washington. Journal of Sedimentary Petrology 53, 353-369.

Clifton, H.E., Hunter, R.E., Phillips, L., 1971. Depositional structures and process in the non-barred high energy nearshore. Journal of Sedimentary Petrology 41, 651-670.

Coleman, J.M., 1988. Dynamic changes and processes in the Mississippi River delta. American Association of Petroleum Geologists, Bulletin 100, 9991015

Coleman, J.M., Prior, D.B., 1983. Deltaic sand bodies. American Association of Petroleum Geologists, Education Course Notes Series 15, $171 \mathrm{p}$

Colquhoun, G.P., 1995. Siliciclastic sedimentation on a storm- and tide-influenced shelf and shoreline: the Early Devonian Roxburgh Formation, NE Lachlan Fold Belt, southeastern Australia. Sedimentary Geology 97, 69-98.
Cunha, P.R.C., Gonzaga, F.G., Coutinho, L.F.C., Feijó, F.J., 1994. Bacia do Amazonas. Boletim de Geociências da Petrobrás 8, 47-55.

Daemon, R.F., 1975. Contribuição à datação da Formação Altér do Chão, Bacia do Amazonas. Revista Brasileira de Geociências 5, 58-84

Daemon, R.F., Contreras, C.J.A., 1971. 25 Congresso Brasileiro de Geologia Sociedade Brasileira de Geologia, São Paulo, vol. 3, pp. 79-88 (abstract).

Dalrymple, R.W., Zaitlin, B.A., Boyd, R., 1992. Estuarine facies models: conceptual basis and stratigraphic implications. Journal of Sedimentary Petrology 62, 1130-1146.

Dino, R., Silva, O.B., Abrahão, D., 1999. 5 Simpósio Sobre o Cretáceo do Brasil, UNESP, Serra Negra, São Paulo, pp. 557-565 (expanded abstract).

Dott, R.H., Bourgeois, J., 1982. Hummocky stratification: significance of its variable bedding sequences. Geological Society of America, Bulletin 93, 663-680.

Driese, S.G., Fischer, M.W., Easthouse, K.A., Marks, G.T., Gogola, A.R., Schoner, A.E., 1991. Model for genesis of shoreface and shelf sandstone sequences, southern Appalachians: paleoenvironmental reconstruction of an Early Silurian shelf system. In: Swift, D.J.P., Oertel, G.F., Tillman, R.W., Thorne, J.A. (Eds.), Shelf Sand and Sandstone Bodies, Geometry, Facies and Sequence Stratigraphy. International Association of Sedimentologists, Special Publication 14, 309-338.

Duke, W.L., Prave, A.R., 1991. Storm- and tide-influenced prograding shoreline sequences in the Middle Devonian, Mahantango Formation, Pennsylvanian. In: Smith, D.G., Reinson, G.E., Zaitlin, B.A., Rahmani, R.A (Eds.), Clastic Tidal Sedimentology. Canadian Society of Petroleum Geologists, Memoir 16, 349-370.

Edwards, M.B., 1995. Differential subsidence and preservation potential of shallow-water Tertiary sequences, northern Gulf Coast Basin, USA. In: Plint, A.G. (Ed.), Sedimentary Facies Analysis. International Association of Sedimentologists, Special Publication 22, 265-281.

Eiras, J.F., Becker, C.R., Souza, E.M., Gonzaga, F.G, Silva, J.G.F., Daniel, L.M.F., Matsuda, N.S., 1993. Revisão estratigráfica da bacia Sedimentar do Solimões, norte do Brasil. Unpublished internal report, Petrobras/ DENOR, Belém.

Eiras, J.F., Becker, C.R., Souza, E.M., Gonzaga, F.G., Silva, J.G.F. Daniel, L.M.F., Matsuda, N.S., Feijó, F.J., 1994. Bacia do Solimões. Boletim de Geociências da Petrobras 8, 17-45.

Ekdale, A.A., Bromley, R.G., 2003. Paleoethologic interpretation of complex Thalassinoides in shallow-marine limestones, Lower Ordovician, southern Sweden. Palaeogeography, Palaeoclimatology, Palaeocology 192, 221-227.

Ekdale, A.A., Bromley, R.G., Pemberton, S.G., 1984. Ichnology: the Use of Trace Fossils in Sedimentology and Stratigraphy. Society of Economic Paleontologists and Mineralogists, Short Course Notes 15, 317 pp.

Elliott, T., 1986. Deltas. In: Reading, H.G. (Ed.), Sedimentary Environments and Facies. Blackwell, Oxford, 615 pp.

Frey, R.W., 1975. The Study of Trace Fossils. Springer, New York, 562 pp.

Glover, B.W., O’Beirne, A.M., 1994. Anatomy, hydrodynamics and depositional setting of a Westphalian C lacustrine delta complex, West Midlands, England. Sedimentology 41, 115-132.

Gingras, M.K., Pemberton, S.G., Saunders, T., Clifton, H.E., 1999. The ichnology of modern and Pleistocene brackish-water deposits at Willapa Bay, Washington: variability in estuarine settings. Palaios 14, 352-374.

Griffis, R.B., Suchanek, T.H., 1991. A model of burrow architecture and trophic modes in thalassinidean shrimp (Decapada: Thalassinidea). Marine Ecology Progress Series 79, 171-183.

Hadley, D.F., Elliot, T., 1993. The sequence-stratigraphic significance of erosive-based shoreface sequences in the Cretaceous Mesaverde Group of northwestern Colorado. In: Posamantier, H.W., Summerhayes, C.P., Haq, B.W., Allen, G.P. (Eds.), Sequence Stratigraphy and Facies Associations. International Association of Sedimentologists, Special Publication 18, 521-535

Harris, C.W., Eriksson, K.A., 1990. Allogenic controls on the evolution of storm to tidal shelf sequences in the early Proterozoic Uncompahgre Group, southwest Colorado, USA. Sedimentology 37, 189-213.

Johnson, H.D., Baldwin, C.T., 1986. Shallow siliciclastic seas. In: Reading, H.G. (Ed.), Sedimentary Environments and Facies. Blackwell Scientific Publications, Oxford, pp. 229-282. 
Kistler, P., 1954. Historical résumé of the Amazonas Basin. Unpublished internal report, Petrobras DENOR, Belém.

Koster, E.H., Currie, P.J., Brinkman, D., Johnson, P., Braman, D., 1987. Sedimentology and Paleontology of the Upper Cretaceous Judith River/Bearpaw Formations at Dinosaur Provincial Park, Alberta. Geological Association of Canada Annual Meeting, Field Trip Guidebook 10, 130 pp.

Kreisa, R.D., Moiola, R.J., 1986. Sigmoidal tidal bundles and other tide-generated sedimentary structures of the Curtis Formation, Utah. Geological Society of America, Bulletin 97, 381-387.

Leckie, D.A., Singh, C., 1991. Estuarine deposits of the Albian Paddy Member (Peace River Formation), and lowermost Shaftesbury Formation, Alberta, Canada. Journal of Sedimentary Petrology 61, 825-849.

van Loon, A.J., Brodzikowski, K., 1987. Problems and progress in the research on soft-sediment deformations. Sedimentary Geology 50, 167193.

McCrory, U.C.L., Walker, R.G., 1986. A storm and tidally-influenced prograding shoreline - Upper Cretaceous Milk River Formation of southern Alberta, Canada. Sedimentology 33, 47-60.

MacEachern, J.A., Raychaudhuri, I., Pemberton, S.G., 1992. Stratigraphic applications of the Glossifungites ichnofacies: delineating discontinuities in the rock record. In: Pemberton, S.G. (Ed.), Applications of Ichnology to Petroleum Exploration: a Core Workshop. Society of Economic Paleontologists and Mineralogists, Core Workshop 17, 169-198.

Mills, P.C., 1983. Genesis and diagnostic value of soft-sediment deformation structures - a review. Sedimentary Geology 35, 83-104.

Mowbray, T., Visser, M.J., 1984. Reactivation surfaces in subtidal channel deposits, Oosterschelde, southeast Netherlands. Journal of Sedimentary Petrology 54, 811-824.

Nemec, W., Steel, R.J., Gellerg, U., Collinson, V.D., Presthohm, E., Oxnevad, I.E., 1988. Anatomy of collapsed and re-established delta front in Lower Cretaceous of eastern Spitsbergen: gravitational sliding and sedimentation processes. American Association of Petroleum Geologists, Bulletin $72,454-476$.

Netto, R.G., Rossetti, D.F., 2003. Ichnology and salinity fluctuations a case study in the Early Miocene (Lower Barreiras succession) of São Luís Basin, Maranhão, Brazil. Revista Brasileira de Paleontologia 6, 5-18.

Nio, S.D., Yang, C., 1991. Diagnostic attributes of clastic tidal deposits: a review. In: Reinson, G.E., Zaitlin, B.A., Rahmani, R.A. (Eds.), Clastic Tidal Sedimentology. Canadian Society of Petroleum Geologists, Memoir 16, 3-28.

Nøttvedt, A., Kreisa, R.D., 1987. Model for the combined-flow origin of hummocky cross-stratification. Geology 15, 357-361.

Orton, G.J., Reading, H.G., 1993. Variability of deltac processes in terms of sediment supply, with particular emphasis on grain size. Sedimentology $40,475-512$.

Pemberton, S.G., Frey, R.W., 1985. The Glossifungites ichnofacies: modern examples from the Georgia coast, USA. In: Curran, H.A. (Ed.), Biogenic Structures: Their Use in Interpreting Depositional Environments. Society of Economic Paleontologists and Mineralogists, Special Publication 35, 237-259.

Pemberton, S.G., Wightman, D.M., 1992. Ichnological characteristics of brackish water deposits. In: Pemberton, S.G. (Ed.), Applications of Ichnology to Petroleum Exploration: A Core Workshop. Society of Economic Paleontologists and Mineralogists, Core Workshop 17, 141-167.

Pemberton, S.G., MacEachern, J.A., Frey, R.W., 1992a. Trace fossil facies models: environmental and allostratigraphic significance. In: Walker, R.G., James, N.P. (Eds.), Facies Models Response to Sea Level Changes. Geological Association of Canada. St Johns, Newfoundland, pp. 47-72.

Pemberton, S.G., Reinson, G.E., MacEachern, J.A., 1992b. Comparative ichnological analysis of Late Albian estuarine valley-fill and shelf-shoreface deposits, Crystal Viking Field, Alberta. In: Pemberton, S.G. (Ed.), Applications of Ichnology to Petroleum Exploration: A Core Workshop. Society of Economic Paleontologists and Mineralogists, Core Workshop $17,291-317$

Pemberton, S.G., MacEachern, J., Ranger, M.J., 1992c. Ichnology and event stratigraphy: the use of trace fossils in recognizing tempestites. In: Pemberton, S.G. (Ed.), Applications of Ichnology to Petroleum Exploration. Society of Economic Paleontologists and Mineralogists, Core Workshop 17, 85-117.
Pemberton, S.G., Spila, M., Pulham, A.J., Saunders, T., MacEachern, J.A., Robbins, D., Sinclair, I.K., 2001. Ichnology and sedimentology of shallow to marginal marine systems. Geological Association of Canada, Short Course Notes 15, 343 pp.

Petri, S., Fúlfaro, V.J., 1983. Geologia do Brasil. Editora da Universidade de São Paulo, São Paulo, 631 pp.

Plint, A.G., Norris, B., 1991. Anatomy of a ramp margin sequence: facies successions, paleogeography and sediment dispersal patterns in the Muskiki and Marshybank formations, Alberta Foreland Basin. Canadian Society of Petroleum Geologists, Bulletin 39, 18-42.

Plint, A.G., Walker, R.G., 1987. Cardium Formation 8. Facies and environments of the Cardium shoreline and coastal plain in the Kakwa Field and adjacent areas, northwestern Alberta. Canadian Society of Petroleum Geologists, Bulletin 35, 48-64.

Price, L.I., 1960. Dentes de Theropoda num testemunho de sonda no Estado do Amazonas. Anais da Academia Brasileira de Ciências 32, 79-84.

Raaf, J.M.F., Boersma, J.R., van Gelder, A., 1977. Wave-generated structures and sequences from a shallow marine succession, Lower Carboniferous, County Cork, Ireland. Sedimentology 24, 451-483.

Rossetti, D.F., 1997. Internal architecture of mixed tide and storm-influenced deposits: an example from the Alcântara Formation, northern Brazil. Sedimentary Geology 114, 163-188.

Rossetti, D.F., 1998. Facies architecture and sequential evolution of an incisedvalley estuarine fill: the Cujupe Formation (Upper Cretaceous to ?Lower Tertiary), São Luís Basin, northern Brazil. Journal of Sedimentary Research 68, 299-310.

Rossetti, D.F., Góes, A.M., 2001. Imaging Upper Tertiary to Quaternary deposits from northern Brazil applying ground-penetrating radar. Revista Brasileira de Geociências 31, 195-202.

Rossetti, D.F., Góes, A.M., 2004. Caracterização paleoambiental de depósitos albianos na borda sul da Bacia de São Luís-Grajaú: modelo de delta fluvial influenciado pó tempestade. Revista Brasileira de Geociências 3, 299-312.

Rossetti, D.F., Santos Jr., A.E., 2003. Events of soft sediment deformation and mass failure in Upper Cretaceous estuarine deposits (Cametá Basin, northern Brazil) as evidence for seismic activity. Sedimentary Geology 161, 107-130.

Rossetti, D.F., Truckenbrodt, W., Góes, A.M., 1989. Estudo paleoambiental e estratigráfico dos Sedimentos Barreiras e Pós-Barreiras na região Bragantina, nordeste do Pará. Boletim do Museu Paraense Emílio Goeldi. Série Ciências da Terra 1, 25-74.

Rossetti, D.F., Góes, A.M., Truckenbrodt, W., Anaisse Jr., J., 2000. Tsunamiinduced large-scale scour-and-fill structures in Albian to Cenomanian deposits of Grajaú Basin, northern Brazil. Sedimentology 47, 309-323.

Shanley, K.W., McCabe, P.J., Hettinger, R.D., 1992. Tidal influence in Cretaceous fluvial strata from Utah: a key to sequence stratigraphic interpretation. Sedimentology 39, 905-930.

Sheenan, P.M., Schiefelbein, D.R.J., 1984. The trace fossil Thalassinoides from the Upper Ordovician of the eastern Great Basin: deep burrowing in the Early Paleozoic. Journal of Paleontology 58, 440-447.

Shepard, F.P., 1955. Delta front valleys bordering Mississippi distributaries. Geological Society of America, Bulletin 66, 1489-1498.

Shukla, U.K., Kotlia, B.S., Mathur, P.D., 2002. Sedimentation pattern in a trans-Himalaian Quaternary lake at Lamayuru (Ladakh), India. Sedimentary Geology 148, 405-424.

Simpson, E.L., Eriksson, K.A., 1991. Depositional facies and controls on parasequence development in siliciclastic tidal deposits from the Lower Proterozoic, Upper Mount Guide Quartzite, Mount Isa Inlier, Australia. In: Smith, Reinson, G.E., Rahmani, R.A. (Eds.), Clastic Tidal Sedimentology. Canadian Society of Petroleum Geologists, Memoir 16, 371-387.

Swift, D.J.P., Figueiredo Jr., Freeland, G.L., Oertel, G.F., 1983. Hummocky cross-stratification and megaripples: a geological double standard? Journal of Sedimentary Petrology 53, 1295-1317.

Tassinari, C.C.G., Macambira, M.J.B., 1999. Geochronological provinces of the Amazonian Craton. Episodes 22, 174-182.

Tassinari, C.C.G., Bittencourt, J.S., Geraldes, M.C., Macambira, M.J.B., Lafon, J.M., 2000. The Amazon Craton. In: Cordani, U.G., ThomazFilho, A., Campos, D.A. (Eds.), Tectonic Evolution of South America. 
Academia Brasileira de Ciências, Special Publication of the 31th International Geological Congress, pp. 41-95.

Teixeira, W., Tassinari, C.C.G., Cordani, U.G., Kawashita, K., 1989. A review of the geochronology of the Amazonian Craton: tectonic implications. Precambrian Research 42, 213-227.

Uchman, A., 1995. Taxonomy and palaeoecology of flysch trace fossils: the Marnoso-arenacea Formation and associated facies (Miocene, Northern Apennines, Italy). Beringeria 15, 3-115.

Visser, M.J., 1980. Neap-spring cycles reflected in Holocene subtidal largescale bedform deposits, a preliminary note. Geology 8, 543-546.

Walker, R.G., 1984. Shelf and shallow marine sands. In: Walker, R.G. (Ed.), Facies Models. Geosciences Canada Reprint Series 1, $141-170$.
Watkins, R., Coorough, P.J., 1997. Silurian Thalassinoides in an offshore carbonate community, Wisconsin, USA. Palaeogeography, Palaeoclimatology, Palaeocology 129, 109-117.

Wightman, D.M., Pemberton, S.G., Singh, C., 1987. Depositional modeling of the Upper Mannville (Lower Cretaceous), east central Alberta: implications for the recognition of brackish water deposits. In: Tillman, R.W., Weber, K.J. (Eds.), Reservoir Sedimentology. Society of Economic Paleontologists and Mineralogists, Special Publication 40, 189-220.

Wignall, P.B., 1991. Dysaerobic trace fossils and ichnofabrics in the Upper Jurassic Kimmeridge Clay of southern England. Palaios 6, 264-270.

Yang, C.S., Nio, S.D., 1985. The estimation of paleohydrodynamic processes from subtidal deposits using time series analysis methods. Sedimentology $32,41-57$. 